\title{
Alpha-Ketoglutarate: A Potential Inner Mitochondrial and Cytosolic Protector against Peroxynitrite and Peroxynitrite-Induced Nitration?
}

\author{
Joachim Greilberger ${ }^{1,2, *}$, Michaela Greilberger ${ }^{2}$, Reinhold Wintersteiger ${ }^{3}$, Klaus Zangger $^{4}$ and Ralf Herwig ${ }^{5}(\mathbb{C}$ \\ 1 Otto Loewi Research Center for Vascular Biology, Immunology and Inflammation, \\ Division of Physiological Chemistry, Medical University of Graz, 8010 Graz, Austria \\ 2 Schwarzl Medical Center, Institute of Scientific Laboratory, 8301 Graz, Austria; institut@laborwissenschaft.at \\ 3 Department of Pharmaceutical Chemistry, Institute of Pharmaceutical Sciences, University of Graz, \\ 8010 Graz, Austria; reinhold.wintersteiger@uni-graz.at \\ 4 Institute of Chemistry, Organic and Bioorganic Chemistry, University of Graz, 8010 Graz, Austria; \\ klaus.zangger@uni-graz.at \\ 5 German Medical Center, Department of Urology Surgery, Dubai 665664, United Arab Emirates; \\ dr.ralf.herwig@gmail.com \\ * Correspondence: joachim.greilberger@medunigraz.at
}

Citation: Greilberger, J.; Greilberger, M.; Wintersteiger, R.; Zangger, K.; Herwig, R. Alpha-Ketoglutarate: A Potential Inner Mitochondrial and Cytosolic Protector against Peroxynitrite and PeroxynitriteInduced Nitration? Antioxidants 2021, 10, 1501. https://doi.org/10.3390/ antiox10091501

Academic Editors:

Eftekhar Eftekharpour and Susan Logue

Received: 25 August 2021

Accepted: 17 September 2021

Published: 21 September 2021

Publisher's Note: MDPI stays neutral with regard to jurisdictional claims in published maps and institutional affiliations.

Copyright: (c) 2021 by the authors. Licensee MDPI, Basel, Switzerland. This article is an open access article distributed under the terms and conditions of the Creative Commons Attribution (CC BY) license (https:// creativecommons.org/licenses/by/ $4.0 /)$.
Abstract: The generation of peroxynitrite $\left(\mathrm{ONOO}^{-}\right)$is associated with several diseases, including atherosclerosis, hypertension, neurodegeneration, cancer, inflammation, and sepsis. Alphaketoglutarate $(\alpha \mathrm{KG})$ is a known potential highly antioxidative agent for radical oxidative species such as peroxides. The question arises as to whether $\alpha \mathrm{KG}$ is also a potential scavenger of $\mathrm{ONOO}^{-}$ and a potential protector against $\mathrm{ONOO}^{-}$-mediated nitration of proteins. NMR studies of $1 \mathrm{mM}$ $\alpha \mathrm{KG}$ in $100 \mathrm{mM}$ phosphate-buffered saline at $\mathrm{pH} 7.4$ and $\mathrm{pH} 6.0$ were carried out in the presence or absence of a final concentration of $2 \mathrm{mM} \mathrm{ONOO}^{-}$. An $\mathrm{ONOO}^{-}-$luminol-induced chemiluminescence reaction was used to measure the scavenging function of several concentrations of $\alpha \mathrm{KG}$; quantification of $\alpha \mathrm{KG}$ was performed via spectrophotometric enzymatic assay of $\alpha \mathrm{KG}$ in the absence or presence of 0,1 , or $2 \mathrm{mM} \mathrm{ONOO}^{-}$. The nitration of tyrosine residues on proteins was measured on $\mathrm{ONOO}^{-}$-treated bovine serum albumin (BSA) in the presence or absence of $0-24 \mathrm{mM} \alpha \mathrm{KG}$ by an ELISA technique using a specific anti-IgG against nitro-tyrosine. The addition of $\mathrm{ONOO}^{-}$to $\alpha \mathrm{KG}$ led to the formation of succinic acid and nitrite at $\mathrm{pH}$ 7.0, but not at $\mathrm{pH}$ 6.0, as $\alpha \mathrm{KG}$ was stable against $\mathrm{ONOO}^{-}$. The absorbance of enzymatically estimated $\alpha \mathrm{KG}$ at the time point of $30 \mathrm{~min}$ was significantly lower in favour of $\mathrm{ONOO}^{-}(1 \mathrm{mM}: 0.21 \pm 0.03,2 \mathrm{mM}$ : $0.12 \pm 0.05$ vs. $0 \mathrm{mM}: 0.32 \pm 0.02$; $p<0.001)$. The luminol technique showed an inverse logarithmic correlation of the $\mathrm{ONOO}^{-}$and $\alpha \mathrm{KG}$ concentrations $\left(y=-2 \times 10^{5} \ln (x)+1 \times 10^{6} ; r^{2}=0.99\right)$. The usage of $4 \mathrm{mM} \alpha \mathrm{KG}$ showed a significant reduction by nearly half in the chemiluminescence signal $(284,456 \pm 29,293 \mathrm{cps}, p<0.001)$ compared to the control $(474,401 \pm 18,259)$; for 20 and $200 \mathrm{mM} \alpha \mathrm{KG}$, there were further reductions to $163,546 \pm 26,196 \mathrm{cps}(p<0.001)$ and $12,658 \pm 1928 \mathrm{cps}(p<0.001)$. Nitrated tyrosine residues were estimated using the ELISA technique. A negative linear correlation was obtained by estimating nitrated tyrosine residues in the presence of $\alpha \mathrm{KG}\left(r^{2}=0.94\right)$ : a reduction by half of nitrated tyrosine was estimated using $12 \mathrm{mM} \alpha \mathrm{KG}$ compared to the control $(326.1 \pm 39.6 \mathrm{nmol}$ vs. $844.5 \pm 128.4 \mathrm{nmol}$; $p<0.001)$.

Keywords: alpha-ketoglutarate $(\alpha \mathrm{KG})$; peroxynitrite $\left(\mathrm{ONOO}^{-}\right)$; reactive oxygen and nitrogen species (RONS)

\section{Introduction}

$\alpha \mathrm{KG}$ is widely known as an intermediate of the Krebs cycle and the natural ubiquitous collector of amino groups in body tissues. It has a potent 'sparing' effect on endogenous glutamine pools and a synergistic effect on the synthesis of glutamine. We have seen 
that $\alpha \mathrm{KG}$ dramatically increases the synthesis of arginine, proline, and polyamines and reduces oxidative stress, which also play a key role in metabolic adaptation before and after surgery [1]. $\alpha \mathrm{KG}$ is involved as a co-substrate in 2-oxo-glutarate-dependent dioxygenase and hypoxia inducing factor (HIF-1) and as a substrate of the Jumonji C domain-containing lysine demethylases (KDM2-7). Besides these functions, $\alpha \mathrm{KG}$ is involved in the energygenerating process, wherein $\alpha \mathrm{KG}$ is led by the formation of $\mathrm{NAD}^{+}$over $\mathrm{NADH}^{+}$to form carbon dioxide and succinyl-CoA or by an overflow of $\mathrm{NADH}^{+}$to generate glutamate by up-regulating the glutamate dehydrogenase pathway. $\alpha \mathrm{KG}$ can be formed enzymatically by the oxidative decarboxylation of isocitrate (isocitrate dehydrogenase), by the glutamatepyruvate pathway (glutamate-pyruvate transaminase), and by the reversible transfer of amino groups from glutamate to oxalate by glutamate-oxaloacetate transaminase in either the inner-mitochondrial-membrane or cytoplasmic form.

$\alpha \mathrm{KG}$ is known to react with $\mathrm{H}_{2} \mathrm{O}_{2}$ non-enzymically to form succinate and carbon dioxide in several biological systems, including cell cultures [2] in vitro and in vivo [3] and even in cell culture media alone [4]. We recently reported that $\alpha \mathrm{KG}$ reduced oxidatively modified proteins in the presence of cigarette smoke radicals, estimated from the content of carbonyl proteins [5]. Additionally, our group reported that oral supplementation with $\alpha \mathrm{KG}$ effectively increased the energy level and reduced the oxidative stress situation during surgery, as measured by the content of oxidatively modified proteins, compared to the placebo group, which resulted in a better recovery and lower hospitalisation time [1].

Peroxynitrite is a biological oxidising and nitrating agent generated physiologically by the superoxide anion radical $\left(\mathrm{O}_{2}{ }^{\bullet-}\right)$ and $\mathrm{NO}^{\bullet}$ [6]. The nitration of tyrosine residues on proteins seems to take place in the normal ageing process [7], but also in the progress of a variety of diseases such as atherosclerosis, hypertension, neurodegeneration, inflammation, cancer, and sepsis [8,9]. For example, protein tyrosine nitration was shown to take place in the apoptosis of cultured motoneurons [10] and in an amyloid lateral sclerosis animal model during its progression [11].

So, strategies are needed to reduce peroxynitrite and the nitration levels of protein tyrosine. Indirect pathways such as increasing SOD activity by organic selenium compounds [12] or direct administration of endo- or exogenous uric acid resulted in a decrease of peroxynitrite and protein tyrosine nitration [13]. Inner-mitochondrial and cytoplasmic compounds such as $\alpha \mathrm{KG}$ seem to have a positive effect in reducing peroxides, and it was speculated that $\alpha \mathrm{KG}$ might also have antioxidative potential against peroxynitrite [14]. The aim of this study was to estimate the potential effect of $\alpha \mathrm{KG}$ to reduce peroxynitrite and to inhibit protein tyrosine nitration.

\section{Materials and Methods}

\subsection{Materials}

The following materials Sigma Aldrich, Vienna, Austria, USA), $\mathrm{NaNO}_{2}$ (Sigma Aldrich, Vienna, Austria), $\mathrm{NaOH}$ (Merck, Darmstadt, Germany), $\mathrm{MnO}_{2}$ (Sigma Aldrich, Vienna, Austria), luminol (3-amino-phtalhydrazid, Sigma Aldrich, Vienna, Austria), bovine serum albumin (BSA; Sigma Aldrich, Vienna, Austria), rabbit anti-nitro-tyrosine IgG (Cayman Europe, Tallinn, Estonia USA), goat anti-rabbit IgG-HRP (Agilent Technologies, Santa Clara, USA), TMB and stop solution (Immundiagnostik, Bensheim, Germany), Tween 20 (Sigma Aldrich, Vienna, Austria), I-Block (ThermoFisher, Vienna, Austria), alpha-ketoglutarate $(\alpha \mathrm{KG})$, and an alpha-ketoglutarate enzymatic kit (Sigma Aldrich, Vienna, Austria).

\subsection{Nuclear Magnetic Resonance Spectroscopy}

Solutions of $1 \mathrm{mM} \alpha \mathrm{KG}$ in $100 \mathrm{mM} \mathrm{KPi}$ at $\mathrm{pH} 7.4$ and 6.0 were used. To enable field-frequency locking for the NMR experiments, $10 \% \mathrm{D}_{2} \mathrm{O}$ was added. Peroxynitrite stock solutions ( $20 \mathrm{mM})$ were added to yield final concentrations of $2 \mathrm{mM}$. All NMR spectra were acquired at $300 \mathrm{~K}$ on a Bruker Avance DRX 500 NMR spectrometer, equipped with a 
TXI $5 \mathrm{~mm}$ probe with z-axis gradients. Carbon chemical shifts were obtained from a 2D ${ }^{1} \mathrm{H}-{ }^{13} \mathrm{C}$ HSQC experiment.

\subsection{Preparation of $\mathrm{ONOO}^{-}$}

$\mathrm{ONOO}^{-}$was prepared according to Hughes and Nicklin [15] by incipient mixing of equal volumes of $0.7 \mathrm{M} \mathrm{H}_{2} \mathrm{O}_{2}$ solution in $0.6 \mathrm{M} \mathrm{HCl}$ and $0.6 \mathrm{M} \mathrm{NaNO}_{2}$ on ice, followed immediately by termination of the reaction with $1.5 \mathrm{M} \mathrm{NaOH}$. Surplus $\mathrm{H}_{2} \mathrm{O}_{2}$ was removed by the addition of a pinch of $\mathrm{MnO}_{2}$ and subsequent filtration of the suspension. The $\mathrm{ONOO}^{-}$concentration was determined spectrophotometrically at $302 \mathrm{~nm}$ with an extinction coefficient of $1670 \mathrm{M}^{-1} \mathrm{~cm}^{-1}$. Aliquots were stored at $-70{ }^{\circ} \mathrm{C}$ until measurements.

\subsection{Enzymatically Colorimetric $\alpha K G$ Quantification Assay Kit}

In the assay, $\alpha K G$ was transaminated with the generation of pyruvate, which was utilised to convert a nearly colourless probe to colour $\left(\lambda_{\max }=570 \mathrm{~nm}\right)$. The $\alpha \mathrm{KG}$ standard was pre-incubated at room temperature for $30 \mathrm{~min}$ with different concentrations of $\mathrm{ONOO}^{-}$. Aliquots were transferred to a microtitration plate and mixed with assay buffer and reaction mix according to the protocol. After $30 \mathrm{~min}$, the absorbance at $570 \mathrm{~nm}$ was measured. For kinetic experiments, OD $570 \mathrm{~nm}$ was measured every $5 \mathrm{~min}$ between 0 and $70 \mathrm{~min}$.

\section{5. $\mathrm{ONOO}^{-}$-Luminol Measurements Using $\alpha \mathrm{KG}$}

The consumption of peroxynitrite was measured via a luminescence technique [16]. A volume of $5 \mu \mathrm{L}$ of $30 \mathrm{mM} \mathrm{ONOO}^{-}$was transferred to a white 96-well microtitration plate (Nunc, Roskilde, Denmark). Different concentrations of $\alpha$ KG were pipetted directly into the $\mathrm{ONOO}^{-}$. Immediately, after one second, luminol ( $400 \mu \mathrm{M}$ 3-amino-phtalhydrazide in $10 \mathrm{mM}$ PBS, pH 7.4) was added (total reaction volume $200 \mu \mathrm{L}$ ), and the chemiluminescence signal was detected on a BMG Lumistar plate reader (ServoLAB, Graz, Austria) each second for a duration of one minute. The luminescence signal was expressed in counts per second (cps).

\subsection{Nitration of $B S A$ with $\mathrm{ONOO}^{-}$}

A quantity of $2 \mathrm{mg}$ albumin was dissolved in $800 \mu \mathrm{L}$ of $10 \mathrm{mM}$ phosphate-buffered saline ( $\mathrm{pH} 7.4)$ in the presence or absence of $0-24 \mathrm{mM} \alpha \mathrm{KG}$. Three volumes $(400 \mu \mathrm{L})$ of $\mathrm{ONOO}^{-}$solution were added in three steps (every $10 \mathrm{~min}$ ) to obtain a total volume of $2 \mathrm{~mL}$ with an $\mathrm{ONOO}^{-}$end concentration of $12 \mathrm{mM}$. The total reaction time was $30 \mathrm{~min}$ at $37^{\circ} \mathrm{C}$ in a closed tube. After the reaction, a $1 \mathrm{~mL}$ aliquot was used immediately for the determination of nitro-tyrosine-BSA via an ELISA technique. One millilitre of nitrated tyrosine BSA was dialyzed without $\alpha \mathrm{KG}$ in $10 \mathrm{mM}$ PBS pH 7.4 overnight, changing the buffer solution 3 times $(3 \times 1 \mathrm{~L})$. Dialyzed samples were spectrophotometrically (Beckmann spectrophotometer DU 640) measured at $438 \mathrm{~nm}$, and the concentration of nitrated tyrosine on BSA was calculated with an extinction coefficient of $\mathrm{e}=4300 \mathrm{M}^{-1} \mathrm{~cm}^{-1}$ as described earlier. This nitrated tyrosine BSA was used as a standard for the ELISA technique.

\subsection{Estimation of Nitrated Tyrosine BSA by an ELISA Technique}

A quantity of $12 \mathrm{mM}$ nitrated tyrosine BSA $(2 \mathrm{mg} / \mathrm{mL})$ was used as the standard. Volumes of $200 \mu \mathrm{L}$ of several diluted BSA solutions $(3.12,1.56,0.78$, and $0.39 \mu \mathrm{g} / \mathrm{mL})$ in the absence or presence of $12 \mathrm{mM} \alpha \mathrm{KG}$ were applied to a transparent 96-well microtitration plate (Nunc, Roskilde, Denmark) and incubated at $37^{\circ} \mathrm{C}$ for $2 \mathrm{~h}$. After three washes (washing buffer: $10 \mathrm{mM}$ PBS + $0.01 \%$ tween 20, pH 7.4) with an Auto Plate Washer EL X 450 (BioTek, Bad-Friedrichshall, Germany), $250 \mu \mathrm{L}$ of blocking solution (0.2\% I-Block in $10 \mathrm{mM}$ PNS, pH 7.4) was pipetted into the wells. After $30 \mathrm{~min}$ at room temperature (RT), the plate was washed again three times with washing buffer. A volume of $200 \mu \mathrm{L}$ of 1:1000 diluted rabbit anti-nitrotyrosine IgG in $10 \mathrm{mM}$ PBS, $\mathrm{pH}$ 7.4, was applied and incubated for $1 \mathrm{~h}$ at $4{ }^{\circ} \mathrm{C}$. After a further washing step $(3 \times g), 200 \mu \mathrm{L}$ of goat anti-rabbit IgG-HRP (1:1000) was added to the samples and incubated for $1 \mathrm{~h}$ at RT. After at least six washes, $200 \mu \mathrm{L}$ 
TMB solution was applied, and the reaction was stopped after 4 min at RT by adding $100 \mu \mathrm{L}$ stop solution. Using a Power WaveX plate photometer (Bio-Tek, USA), extinctions of standards and samples were measured at $490 \mathrm{~nm}$. The molar concentrations of nitrotyrosine on BSA were calculated using the results of the photometrical measurements of $12 \mathrm{mM}$ nitrated tyrosine BSA in the absence of any antioxidants (control). The standard curve was generated using the estimated absorbance. The results of all samples were expressed in nanomoles.

\subsection{Statistical Analysis}

Group comparisons were made using $t$-tests where appropriate and indicated. Linear regression and exponential regression curves were calculated based on Pearson regression (SPSS 25, SPSS Inc., Chicago, IL, USA). All values are given as the mean value and standard deviation. Statistical significance was considered at $p<0.01$, with high significance at $p<0.001$.

\section{Results}

\subsection{Nuclear Magnetic Resonance Spectroscopy}

The $\alpha-K G$-keto group of $\alpha \mathrm{KG}$ is shown in Figure 1A; it gave the same signal after incubation with $\mathrm{ONOO}^{-}$at $\mathrm{pH}$ 6.0, whereas the addition of $\mathrm{ONOO}^{-}$to $\alpha \mathrm{KG}_{\text {led to the }}$ immediate formation of succinic acid at pH 7.4 (Figure 1B). The formation of succinic acid was confirmed by its carbon chemical shift as obtained through $2 \mathrm{D}^{1} \mathrm{H}^{13} \mathrm{CHSQC}$.

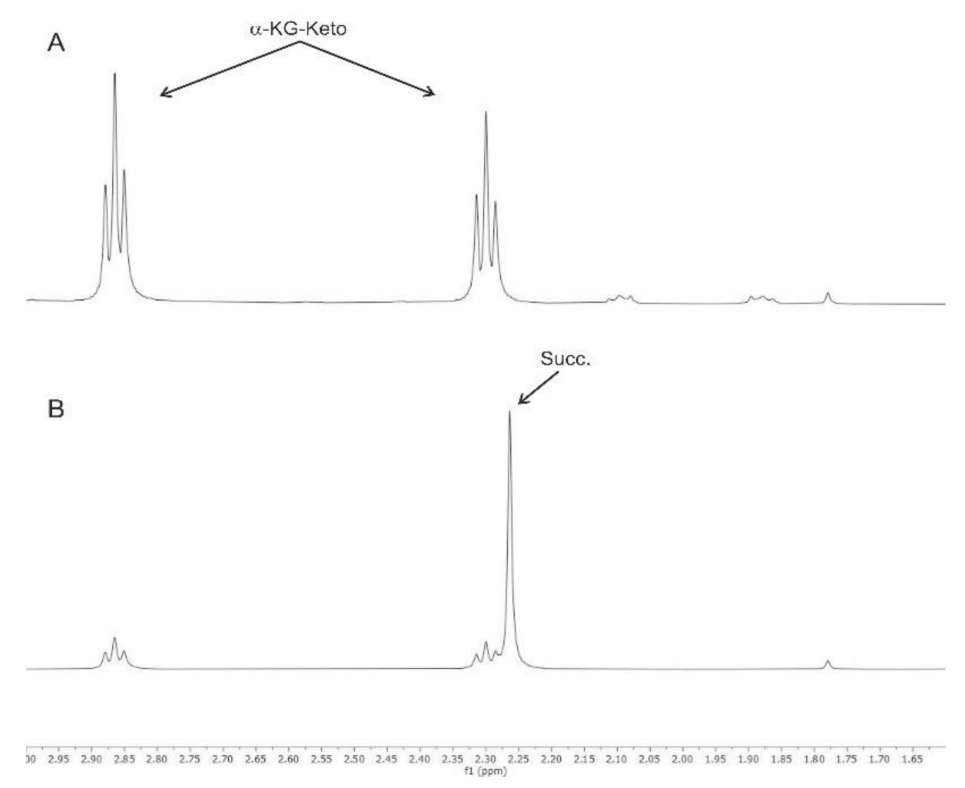

Figure 1. NMR spectra of 2-oxoglutarate $(\alpha \mathrm{KG})$ before and after the reaction with $2 \mathrm{mM} \mathrm{ONOO}-$ at $\mathrm{pH} 6.0$ (A) and after the reaction with $2 \mathrm{mM}$ peroxynitrite at $\mathrm{pH} 7.4(\mathbf{B})$.

\subsection{Enzymatically Colorimetric Assay Kit for $\alpha$ KG Quantification}

Figure 2 shows the enzymatic estimation of $\alpha \mathrm{KG}$ generated in the absence or presence of 0,1 , or $2 \mathrm{mM} \mathrm{ONOO}^{-}(n=5)$. The kinetics of all three $\mathrm{ONOO}^{-}$concentrations $(0,1$, and $2 \mathrm{mM}$ ) between 10 and $70 \mathrm{~min}$ at OD $570 \mathrm{~nm}(\mathrm{~A})$ showed a dose-dependent reduction of $\alpha \mathrm{KG}$ by $\mathrm{ONOO}^{-}$at each time point. The enzymatic reaction was not affected by $\mathrm{ONOO}^{-}$ and, therefore, was also not the active side of the enzyme. According to the protocol, Figure 2B shows the enzymatically estimated $\alpha K G$ concentrations after $30 \mathrm{~min}$ in the absence or presence of $\mathrm{ONOO}^{-}(n=5) . \mathrm{ONOO}^{-}$at $1 \mathrm{mM}$ reduced the absorbance relating to the estimated $\alpha$ KG levels significantly compared to the control $(0.207 \pm 0.020$ OD $570 \mathrm{~nm}$ vs. $0.135 \pm 0.019$ OD $570 \mathrm{~nm} ; p<0.01)$, but $2 \mathrm{mM} \mathrm{ONOO}^{-}$reduced the absorbance even further $(0.082 \pm 0.009$ OD $570 \mathrm{~nm} ; p<0.001)$. 


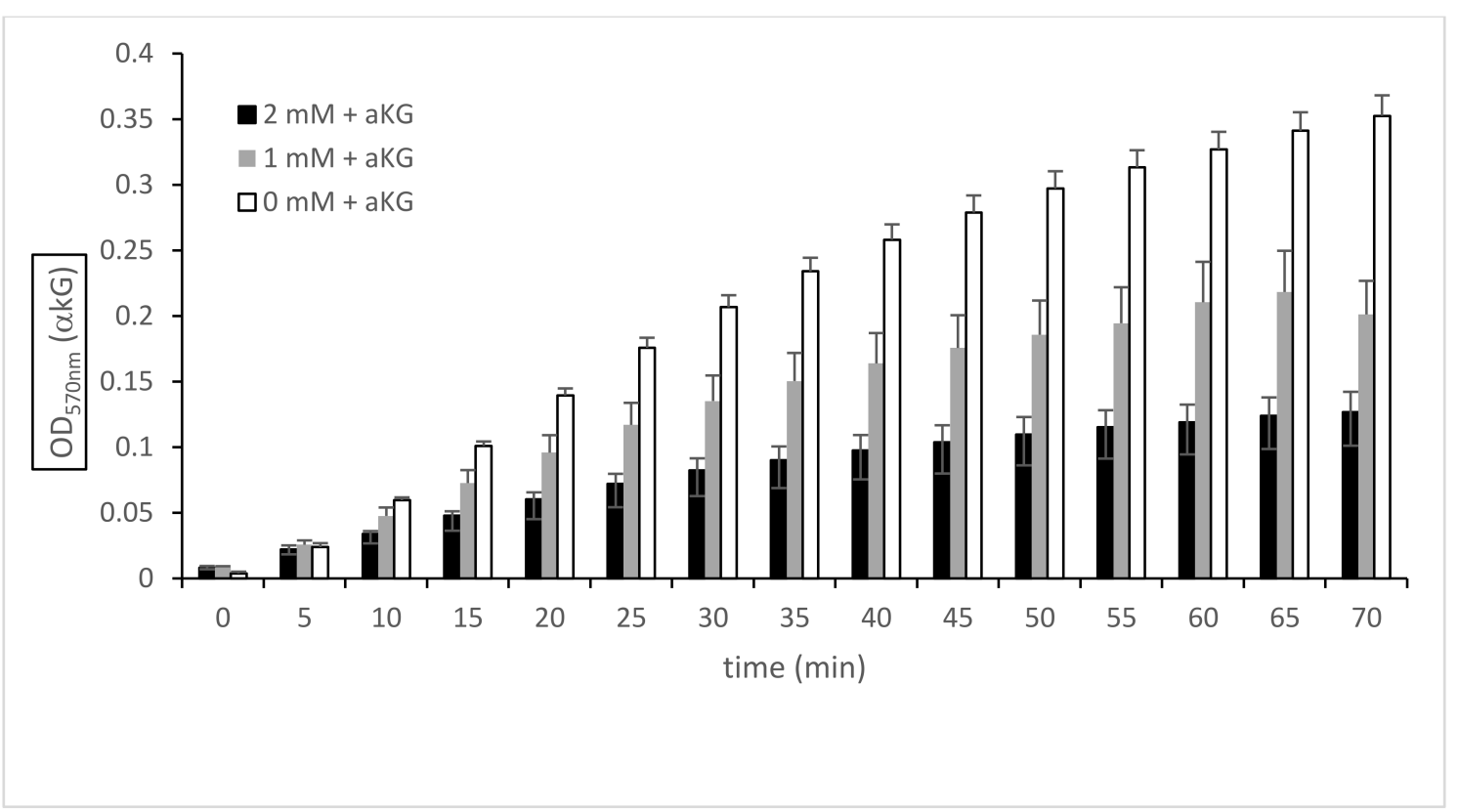

(A)

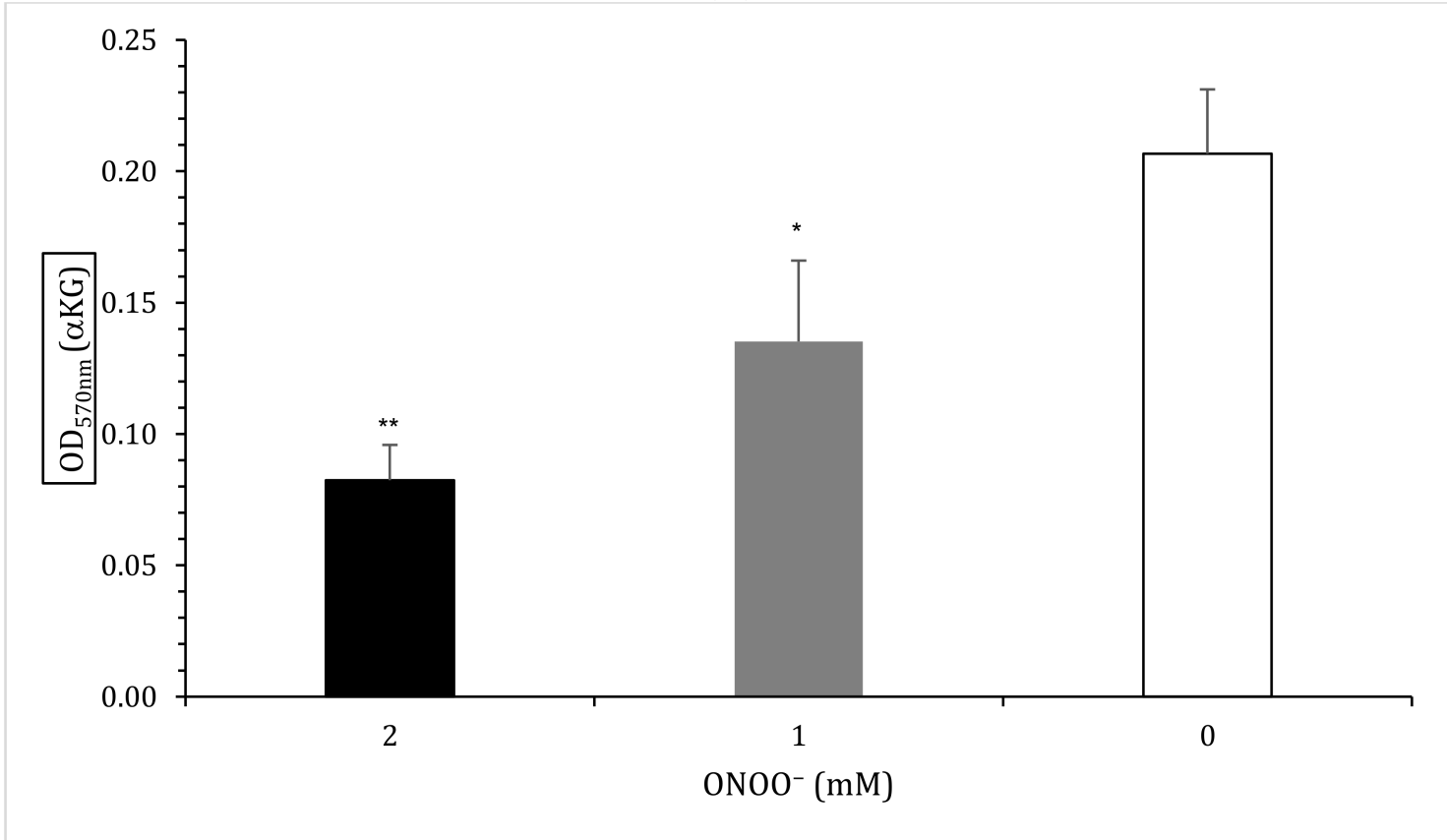

(B)

Figure 2. Spectrophotometric estimation of $\alpha \mathrm{KG}(\mathrm{OD} 570 \mathrm{~nm}$ ) absorbance via an enzyme reaction mix in the absence or presence of $0 \mathrm{mM}$ (white bars; $n=5), 1 \mathrm{mM}$ (grey bars; $n=5$ ), or $2 \mathrm{mM}$ (black bars; $n=5$ ) $\mathrm{ONOO}^{-}$between 0 and $70 \mathrm{~min}(\mathbf{A})$ and after $30 \mathrm{~min}$ according to the protocol (B). ${ }^{*} p<0.01$ : significant compared to the control $\left(0 \mathrm{mM} \mathrm{ONOO}{ }^{-}\right.$, white bar); ** $p<0.001$ : significant compared to the control $\left(0 \mathrm{mM} \mathrm{ONOO}^{-}\right.$, white bar $)$.

\section{3. $\mathrm{ONOO}^{-}$-Luminol-Induced Chemiluminescence in the Presence or Absence of $\alpha \mathrm{KG}$}

Figure $3 \mathrm{~A}$ shows a representative measurement of the $\mathrm{ONOO}^{-}$-luminol-induced chemiluminescence curve in the presence or absence of different concentrations of $\alpha \mathrm{KG}(n=5)$. Using $0.8 \mathrm{mM} \alpha \mathrm{KG}$, a significant reduction in $\mathrm{ONOO}^{-}$to $359,183 \pm 21,604 \mathrm{cps}$ was obtained compared to the control signal in the absence of any antioxidant $(474,401 \pm 18,259 \mathrm{cps}$; $p<0.001$ ) at time point $0 \mathrm{~s}$. Increasing the concentration to $4 \mathrm{mM} \alpha \mathrm{KG}$ showed a reduction by nearly half $(284,456 \pm 29,293$ cps; $p<0.001)$. Using 20 and $200 \mathrm{mM} \alpha \mathrm{KG}$ further 
reduced the signal to $163,546 \pm 26,196 \mathrm{cps}(p<0.001)$ and $12,658 \pm 1928 \mathrm{cps}(p<0.001)$, respectively. The area under the curve (AUC; Figure $3 \mathrm{~B}$ ) of each curve was calculated and showed a negative logarithmic correlation to the $\alpha \mathrm{KG}$ concentration, as shown in Figure 3B $\left(r=0.99 ; y=-2 \times 10^{5} \ln (x)+1 \times 10^{6}\right)$. The calculated point of $50 \%$ reduction was around $12 \mathrm{mM} \alpha \mathrm{KG}$.

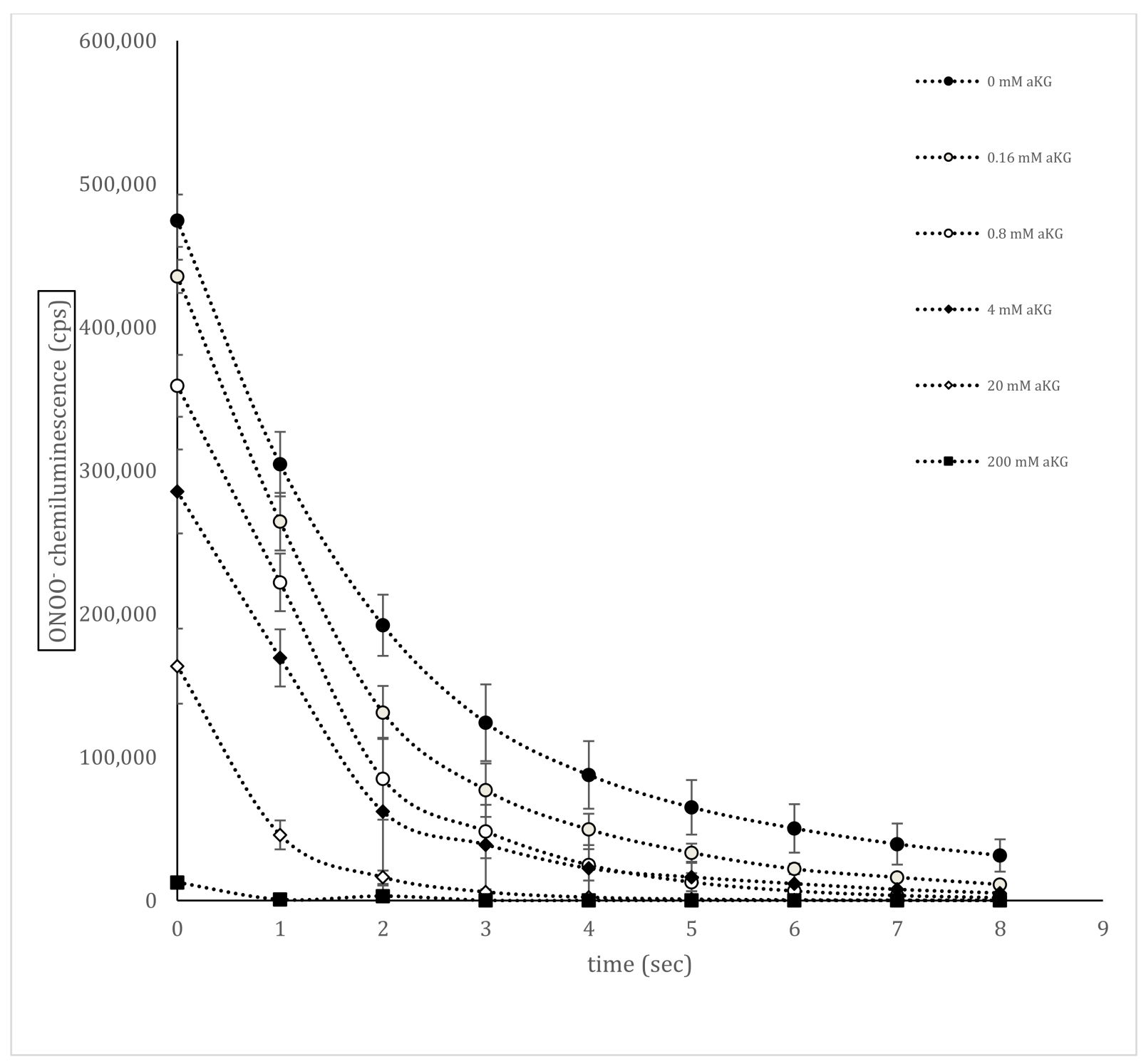

(A)

Figure 3. Cont. 


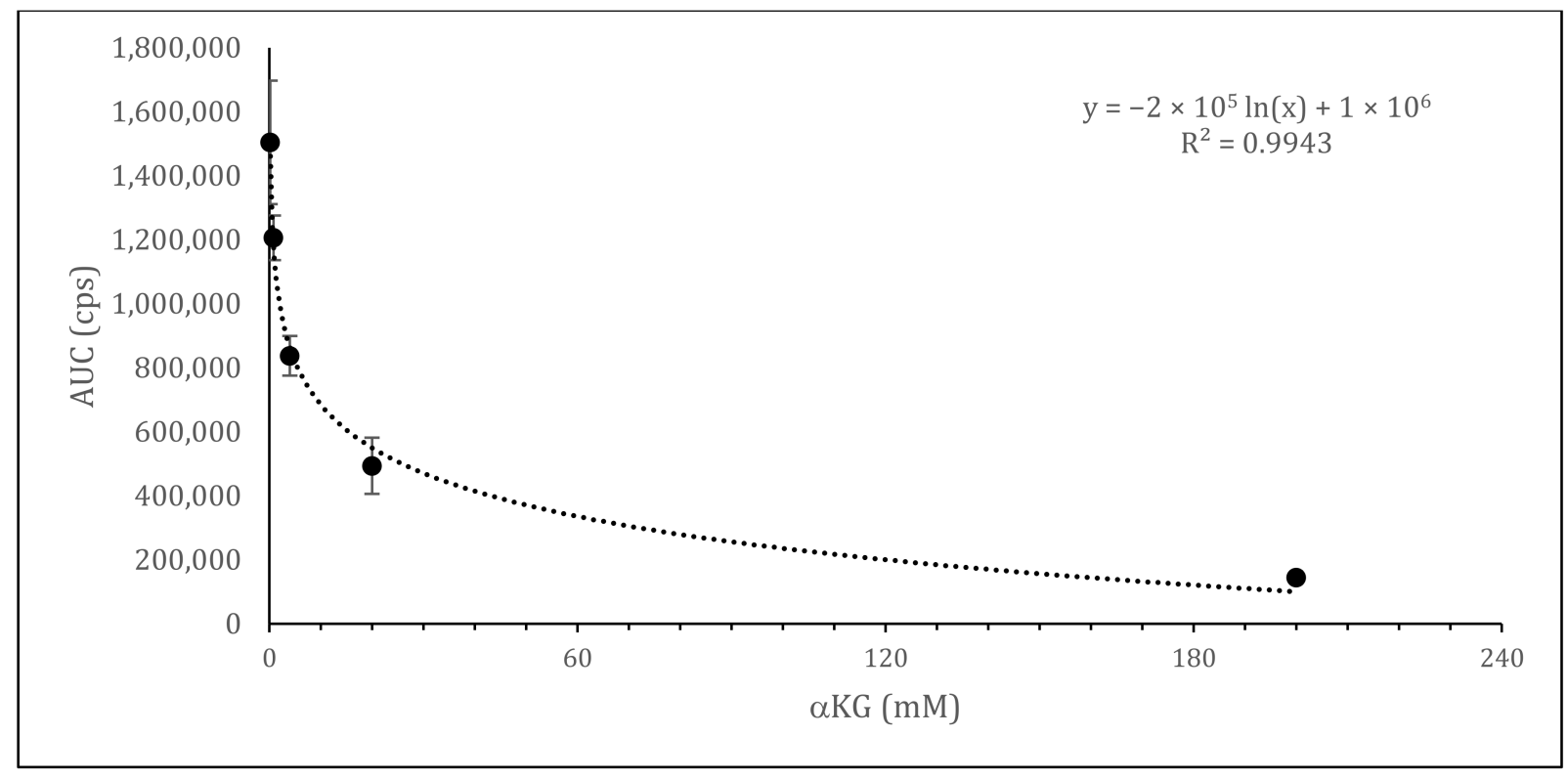

(B)

Figure 3. Standard curves of nitrated tyrosine residues on bovine serum albumin (BSA) using sandwich ELISA measurements $(\mathbf{A} ; n=5)$ and $(\mathbf{B})$ calculated nitro-tyrosine residues on BSA protein in the absence or presence of $0-24 \mathrm{mM} \alpha \mathrm{KG}$. The relation and its regression term between nitrated tyrosine protein and 0 (control), 3, 6, 12, and $24 \mathrm{mM} \alpha \mathrm{KG}$ concentrations $(n=5)$ were calculated. ${ }^{*} p<0.01$ : significant compared to the control; ${ }^{* *} p<0.001$ : significant compared to the control.

\subsection{Nitrated Tyrosine Estimation on BSA in the Presence and Absence of $\alpha K G$}

Figure $4 \mathrm{~A}$ shows the standard curve obtained by the ELISA technique with a highly linear correlation term of $r=0.94$. Incubation of $\mathrm{ONOO}^{-}$with BSA to generate nitrotyrosine residues in the presence of $0-24 \mathrm{mM} \alpha \mathrm{KG}$ led to a negative linear correlation with a high regression term of $r=0.97$ (Figure 4B). While $3 \mathrm{mM} \alpha \mathrm{KG}$ was not able to significantly decrease the amount of nitrated tyrosine residues on BSA compared to the control $(795.5 \pm 13.7 \mathrm{nM}$ vs. $844.5 \pm 42.3 \mathrm{nM}), 6 \mathrm{mM}$ was able to provide a significant reduction $(646.1 \pm 54.4 ; p<0.01)$. Both $12 \mathrm{mM}(326.1 \pm 39.6 \mathrm{nM} ; p<0.001)$ and $24 \mathrm{mM}$ $(130.6 \pm 44.2 \mathrm{nM}) \alpha \mathrm{KG}$ showed a highly significant reduction compared to the control.

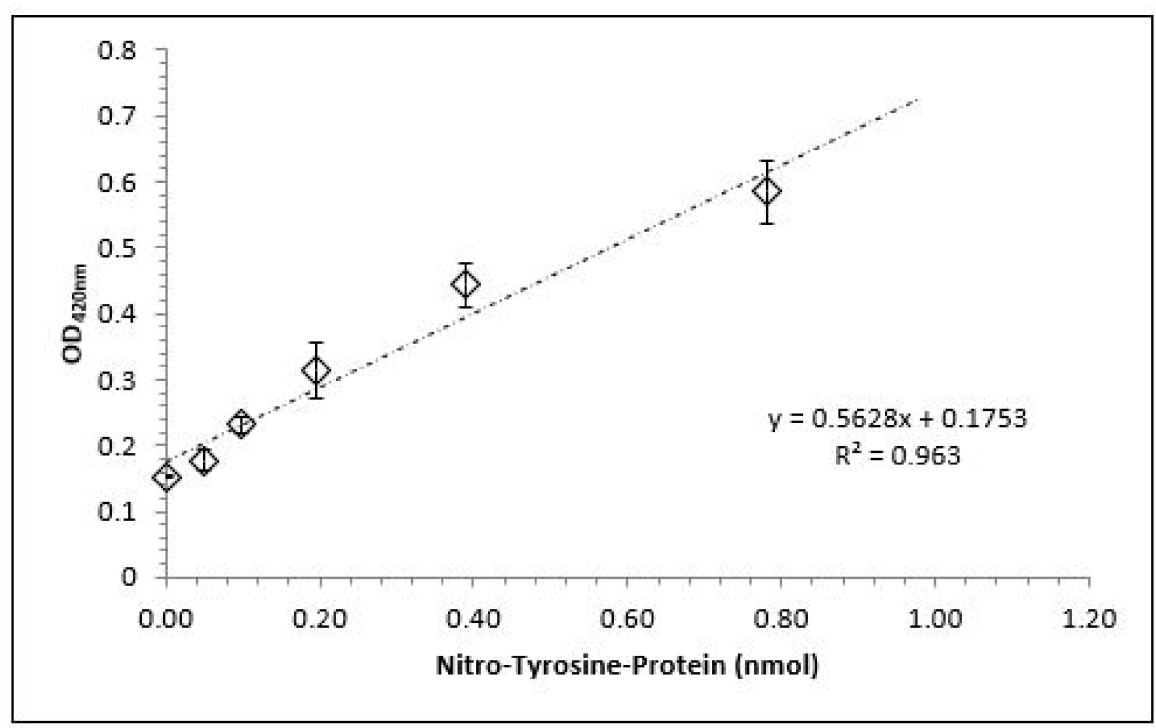

(A)

Figure 4. Cont. 


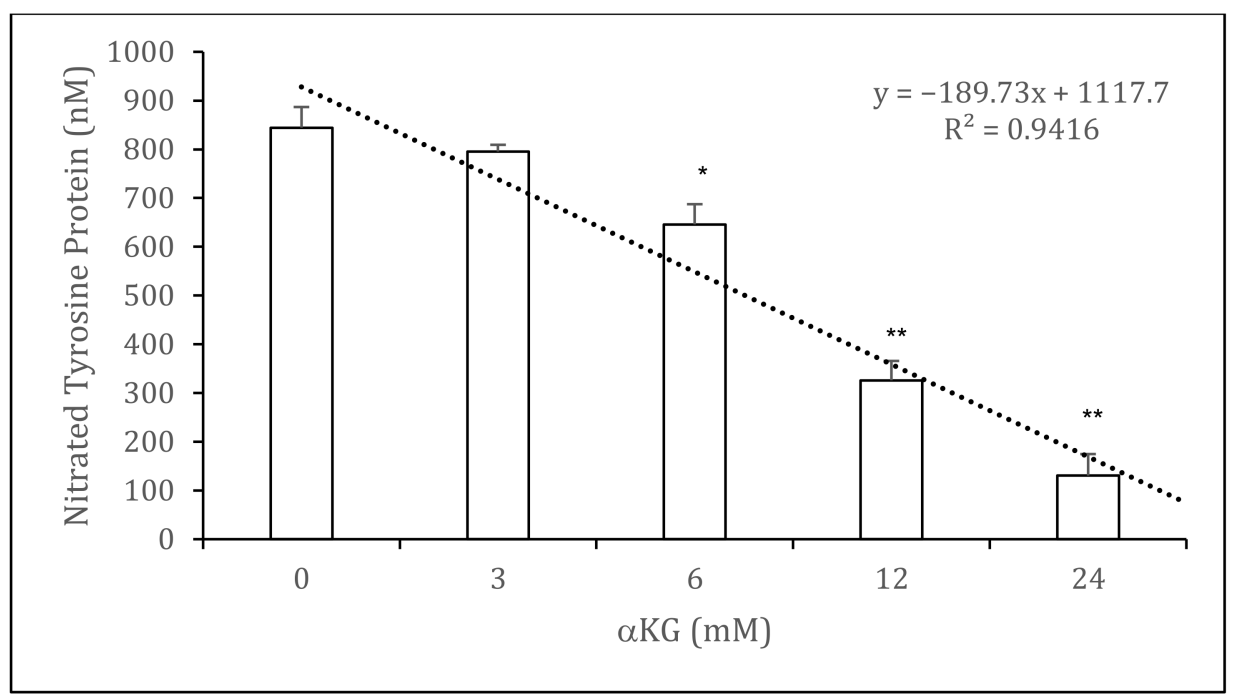

(B)

Figure 4. ELISA measurements of tyrosine residues on bovine serum albumin nitrated by $\mathrm{ONOO}^{-}$. (A) Standard curve of nitrated tyrosine protein $(n=5)$; (B) Estimation of nitro-tyrosine residues on bovine serum albumin in the absence or presence of 0 (control), 3, 6, 12, and $24 \mathrm{mM} \alpha \mathrm{KG}(n=5)$. The relation and its regression term between nitrated tyrosine proteins and $\alpha \mathrm{KG}$ concentrations were calculated. ${ }^{*} p<0.01$ : significant compared to the control; ${ }^{* *} p<0.001$ : highly significant compared to the control.

\section{Discussion}

Recent years have witnessed an avalanche of new knowledge implicating free radicals in virtually every aspect of biology and medicine. It is now axiomatic that the regulated accumulation of RONS contributes to organismal health and well-being. RONS serve as signalling molecules involved in cell growth, differentiation, gene regulation, replicative senescence, and apoptosis [17].

Peroxynitrite is a strong oxidant that can be formed in vivo by the reaction of $\mathrm{O}_{2}{ }^{\bullet-}$ and $\mathrm{NO}^{\bullet}$. The discovery of peroxynitrite as a biological oxidant was seeded by combined data from the physiological and chemical literature [18]. Peroxynitrite is able to mediate oxidation and/or nitration in aqueous phases but also in hydrophobic milieux after free diffusion through membranes [9] to initiate lipid peroxidation and nitration, protein tyrosine nitration, and DNA modifications.

Antioxidant enzymes, such as superoxide dismutase (SOD), control the steady-state levels of peroxynitrite by reducing any overproduced $\mathrm{O}_{2}{ }^{\bullet-}$, e.g., from macrophages, to $\mathrm{H}_{2} \mathrm{O}_{2}$. Uric acid, either endo- or exogenous, is a known antioxidative substance that scavenges peroxynitrite [14]. It is known that $\alpha \mathrm{KG}$ is a potent antioxidative acting substance that reduces $\mathrm{H}_{2} \mathrm{O}_{2}$ to water and succinate. This compound is predominately formed in the inner mitochondria but is also formed quantitatively in cytoplasm. We showed for the first time that $\alpha \mathrm{KG}$ is able to directly reduce peroxynitrite to succinate at physiological $\mathrm{pH}$, as revealed by NMR. It appears that the affinity to reduce $\mathrm{ONOO}^{-}$is very high because of the exponential decrease in the chemiluminescent signal. Using an enzymatic reaction in the quantification of $\alpha \mathrm{KG}, \mathrm{ONOO}^{-}$was also able to eliminate $\alpha \mathrm{KG}$ and not interfere with the enzymatic enzymes.

The nitration of tyrosine usually generates an additional negative charge and adds a relatively bulky substituent to the protein, which may affect the local charge distribution and/or conformation [9]. In vivo nitration of proteins in the presence of peroxynitrite is predominately estimated using the tyrosine residues of proteins such as bovine serum albumin (BSA), haem proteins, SOD, cytochrome c, or fibrinogen kinase glutathione Stransferase [19]. 
We used BSA as the example protein for the nitration of tyrosine residues because of its high level of tyrosine residues per protein. The nitration of tyrosine residues on $\mathrm{BSA}$ with $\mathrm{ONOO}^{-}$was reduced by $\alpha \mathrm{KG}$ : between 0 and $24 \mathrm{mM} \alpha \mathrm{KG}$ showed a negative linear function in preventing the nitration of tyrosine residues. Combining these results with the $\alpha \mathrm{KG}$ enzymatic reaction mix in the spectrophotometric assay, we speculate that the enzymatic active centre might be protected from $\mathrm{ONOO}^{-}$by its substrate $\alpha \mathrm{KG}$. We suggest that this also takes place in other enzymes in which $\alpha \mathrm{KG}$ is a co-factor in the inner mitochondrial membrane, as well as in the cytosol.

$\alpha \mathrm{KG}$ is the obligate co-substrate of Fe(II)/2-oxoglutarate-dependent dioxygenases (OGDD), a superfamily of enzymes that catalyse the oxidative decarboxylation of $\alpha \mathrm{KG}$, producing succinate and $\mathrm{CO}_{2}$ from $\mathrm{O}_{2}$ [20]. Prolyl hydroxylation of hypoxia-inducible factor (HIF)- $\alpha$, as catalysed by the Fe(II)/2-oxoglutarate (AKG)-dependent prolyl hydroxylase domain (PHD) enzymes, has a hypoxia-sensing role in animals [21].

Furthermore, the binding of prolyl-hydroxylated HIF- $\alpha$ to PHD2 is $\sim 50$-fold hindered by prior $\alpha \mathrm{KG}$ binding; thus, when $\alpha \mathrm{KG}$ is limiting, HIF- $\alpha$ degradation might be inhibited by PHD binding [21]. Given that $\alpha \mathrm{KG}$ is a limiting co-substrate for PHD activity during normoxia and that 2-oxoglutarate $(\alpha \mathrm{KG})$ levels depend on amino acid availability, it is possible that PHD activity depends not only on oxygen but also on amino acid availability. This suggests a global metabolic sensor function for PHDs, which could be signalling not only to HIF- $\alpha$ but also to mTOR [22]. We demonstrated first that $\alpha$ KG substitution has clear anticancer activity in vivo $[23,24]$. $\alpha \mathrm{KG}$ was also able to reduce tumour growth and intra-tumoral perfusion $[25,26]$. Those findings were verified by another research group [27]. Furthermore, nitro-tyrosine residue levels on rat myocytes pretreated with an antioxidative solution containing $\alpha \mathrm{KG}$ were significantly lower than those for control rats without pre-treatment [2].

$\alpha \mathrm{KG}$ is a molecule involved in multiple metabolic and cellular pathways. Any loss of $\alpha K G$, e.g., by peroxynitrite or hydrogen peroxide, might result in multiple dysfunctions due to $\alpha \mathrm{KG}^{\prime}$ s several functions as an energy donor, a precursor in amino acid biosynthesis, a signalling molecule, and a regulator of epigenetic processes and cellular signalling via protein binding. In vitro and in vivo antioxidative activities, protection against oxidative stress, and increased energy levels in $\alpha \mathrm{KG}$-supplemented humans were obtained in multiple studies [1,2,23].

$\alpha \mathrm{KG}$ demonstrates a high potential to reduce peroxynitrite to body-suitable products such as succinate and nitrite, and it may protect against the nitration of mitochondrial and cytosolic proteins at neutral $\mathrm{pH}$ in cells and in blood. Nevertheless, further investigations are needed.

Author Contributions: J.G., R.W. and R.H conceived and designed the experiments. J.G., M.G. and K.Z. performed the experiments. J.G., R.W., K.Z. and R.H. analyzed data and J.G. and R.H. wrote the manuscript. J.G., K.Z., R.W. and R.H. contributed reagents/materials/analysis tools. All authors have read and agreed to the published version of the manuscript.

Funding: This research received no external funding.

Institutional Review Board Statement: Not applicable.

Informed Consent Statement: Not applicable.

Data Availability Statement: The data presented in this study are available in the article.

Conflicts of Interest: The authors declare no conflict of interest.

\section{References}

1. Matzi, V.; Lindenmann, J.; Muench, A.; Greilberger, J.; Juan, H.; Wintersteiger, R.; Maier, A.; Smolle-Juettner, F.M. The impact of preoperative micronutrient supplementation in lung surgery. A prospective randomized trial of oral supplementation of combined alpha-ketoglutaric acid and 5-hydroxymethylfurfural. Eur. J. Cardiothorac. Surg. 2007, 32, 776-782. [CrossRef] 
2. Andrä, M.; Russ, M.; Jauk, S.; Lamacie, M.; Lang, I.; Arnold, R.; Brcic, I.; Santos, R.; Wintersteiger, R.; Ortner, A. Antioxidant Solution in Combination with Angiotensin-(1-7) Provides Myocardial Protection in Langendorff-Perfused Rat Hearts. Oxid. Med. Cell. Longev. 2020. [CrossRef] [PubMed]

3. Nath, K.A.; Ngo, E.O.; Hebbel, R.P.; Croatt, A.J.; Zhou, B.; Nutter, L.M. alpha-Ketoacids scavenge H2O2 in vitro and in vivo and reduce menadione-induced DNA injury and cytotoxicity. Am. J. Physiol. 1995, 268, C227-C236. [CrossRef] [PubMed]

4. Long, L.H.; Halliwell, B. Artefacts in cell culture: $\alpha$-Ketoglutarate can scavenge hydrogen peroxide generated by ascorbate and epigallocatechin gallate in cell culture media. Biochem. Biophys. Res. Commun. 2011, 406, 20-24. [CrossRef]

5. Greilberger, J.F.; Wintersteiger, R.; Astrid, O.; Greilberger, M.; Herwig, R. Combination of 2-oxoglutarate/ascorbic acid/5hydroxy-methyl-furfur-aldehyde/carnosine inhibits protein oxidation during radical exposure of cigarette smoke. Proteins 2018, 5, 10-12. [CrossRef]

6. Blough, N.V.; Zafiriou, O.C. Reaction of superoxide with nitric oxide to form peroxonitrite in alkaline aqueous solution. Inorg. Chem. 1985, 24, 3502-3504. [CrossRef]

7. Viner, R.I.; Ferrington, D.A.; Williams, T.D.; Bigelow, D.J.; Schöneich, C. Protein modification during biological aging: Selective tyrosine nitration of the SERCA2a isoform of the sarcoplasmic reticulum Ca2+-ATPase in skeletal muscle. Biochem. J. 1999, 340, 657-669. [CrossRef]

8. Ferrer-Sueta, G.; Campolo, N.; Trujillo, M.; Bartesaghi, S.; Carballal, S.; Romero, N.; Alvarez, B.; Radi, R. Biochemistry of peroxynitrite and protein tyrosine nitration. Chem. Rev. 2018, 118, 1338-1408. [CrossRef] [PubMed]

9. Pacher, P.; Beckman, J.S.; Liaudet, L. Nitric oxide and peroxynitrite in health and disease. Physiol. Rev. 2007, 87, 315-424. [CrossRef]

10. Estévez, A.G.; Spear, N.; Manuel, S.M.; Radi, R.; Henderson, C.E.; Barbeito, L.; Beckman, J.S. Nitric oxide and superoxide contribute to motor neuron apoptosis induced by trophic factor deprivation. J. Neurosci. 1998, 18, 923-931. [CrossRef]

11. Cassina, P.; Cassina, A.; Pehar, M.; Castellanos, R.; Gandelman, M.; de León, A.; Robinson, K.M.; Mason, R.P.; Beckman, J.S.; Barbeito, L.; et al. Mitochondrial dysfunction in SOD1G93A-bearing astrocytes promotes motor neuron degeneration: Prevention by mitochondrial-targeted antioxidants. J. Neurosci. 2008, 28, 4115-4122. [CrossRef]

12. Fiuza, B.; Subelzú, N.; Calcerrada, P.; Straliotto, M.R.; Piacenza, L.; Cassina, A.; da Rocha, J.B.T.; Radi, R.; de Bem, A.F.; Peluffo, G. Impact of SIN-1-derived peroxynitrite flux on endothelial cell redox homeostasis and bioenergetics: Protective role of diphenyl diselenide via induction of peroxiredoxins. Free. Radic. Res. 2015, 49, 122-132. [CrossRef]

13. Hooper, D.; Spitsin, S.; Kean, R.B.; Champion, J.M.; Dickson, G.M.; Chaudhry, I.; Koprowski, H. Uric acid, a natural scavenger of peroxynitrite, in experimental allergic encephalomyelitis and multiple sclerosis. Proc. Natl. Acad. Sci. USA 1998, 95, 675-680. [CrossRef] [PubMed]

14. Halliwell, B.; Gutteridge, J.M.C. Free Radicals in Biology and Medicine, 5th ed.; Oxford University Press: New York, NY, USA, 2015.

15. Hughes, M.N.; Nicklin, H.G. The chemistry of pernitrites. Part I. Kinetics of decomposition of pernitrous acid. J. Chem. Soc. A 1968, 450-452. [CrossRef]

16. Radi, R.; Cosgrove, T.P.; Beckman, J.S.; Freeman, B.A. Peroxynitrite-induced luminol chemiluminescence. Biochem. J. 1993, 290, 51-57. [CrossRef] [PubMed]

17. Vatassery, G.T.; Lai, J.C.; DeMaster, E.G.; Smith, W.E.; Quach, H.T. Oxidation of vitamin E and vitamin C and inhibition of brain mitochondrial oxidative phosphorylation by peroxynitrite. J. Neurosci. Res. 2004, 75, 845-853. [CrossRef] [PubMed]

18. Zdzisińska, B.; Żurek, A.; Kandefer-Szerszeń, M. Alpha-ketoglutarate as a molecule with pleiotropic activity: Well-known and novel possibilities of therapeutic use. Arch. Immunol. Ther. Exp. 2017, 65, 21-36. [CrossRef]

19. Van der Vliet, A.; Hristova, M.; Cross, C.E.; Eiserich, J.P.; Goldkorn, T. Peroxynitrite induces covalent dimerization of epidermal growth factor receptors in A431 epidermoid carcinoma cells. J. Biol. Chem. 1998, 273, 31860-31866. [CrossRef]

20. Souza, J.M.; Peluffo, G.; Radi, R. Protein tyrosine nitration-Functional alteration or just a biomarker. Free. Radic. Biol. Med. 2008, 45, 357-366. [CrossRef]

21. Cobbs, C.S.; Whisenhunt, T.R.; Wesemann, D.R.; Harkins, L.E.; Van Meir, E.G.; Samanta, M. Inactivation of wild-type p53 protein function by reactive oxygen and nitrogen species in malignant glioma cells. Cancer Res. 2003, 63, 8670-8673.

22. Li, X.; De Sarno, P.; Song, L.; Beckman, J.S.; Jope, R.S. Peroxynitrite modulates tyrosine phosphorylation and phosphoinositide signalling in human neuroblastoma SH-SY5Y cells: Attenuated effects in human 1321N1 astrocytoma cells. Biochem. J. 1998, 331, 599-606. [CrossRef] [PubMed]

23. Greilberger, J. Preclinical and clinical testing of a alpha-ketoglutarate/5-HMF/N-actyl-selenomethionine and N-acteyl-methionine for treating tumors. J. Cancer Sci. Ther. 2013, 5, 76.

24. Herwig, R.; Horninger, W.; Pinggera, G.M.; Rehder, P.; Frauscher, F.; Konwalinka, G.; Bartsch, G. Metabolomics therapy with 2-oxo-glutaric acid solution (Karal solution) in patients with hormone and chemotherapy insensitive metastatic prostate cancer leads to an increase of PSA doubling time and decrease of blood supply in tumour lesions. Eur. Urol. Suppl. 2005, 4, 146. [CrossRef]

25. Tennant, D.A.; Gottlieb, E. HIF prolyl hydroxylase-3 mediates alpha-ketoglutarate-induced apoptosis and tumor suppression. $J$ Mol. Med. 2010, 88, 839-849. [CrossRef] [PubMed]

26. Herwig, R.; Greilberger, J. Medication against male infertility (Arzneimittel gegen männliche Sterilität). HG Pharma. Austria 2016, 3, 1-8.

27. Mariacher, C.; Gatterer, H.; Greilberger, J.; Djukic, R.; Greilberger, M.; Philippe, M.; Burtscher, M. Effects of antioxidant supplementation on exercise performance in acute normobaric hypoxia. Int. J. Sport Nutr. Exerc. Metab. 2014, 24, 227-235. [CrossRef] [PubMed] 